\title{
Evaluation of water-saving rice status based on morphophysiological characteristics and water use efficiency
}

\author{
DIDI DARMADI ${ }^{1,2}$, AHMAD JUNAEDI ${ }^{3, \vartheta}$, DIDY SOPANDIE ${ }^{3}$, SUPIJATNO $^{3}$, ISKANDAR LUBIS ${ }^{3}$, \\ KOKI HOMMA ${ }^{4}$, NURIL HIDAYATI \\ ${ }^{1}$ Program of Agronomy and Horticulture, Graduate School, Institut Pertanian Bogor. J1. Meranti, Kampus IPB Dramaga, Bogor 16680, West Java, \\ Indonesia \\ ${ }^{2}$ Assessment Institute for Agricultural Technology, Indonesian Agency for Agricultural Research and Development. J1. Pang Nyak Makam No. 27, Banda \\ Aceh 24415, Aceh, Indonesia \\ ${ }^{3}$ Department of Agronomy and Horticulture, Faculty of Agriculture, Institut Pertanian Bogor. Jl. Meranti, Kampus IPB Dramaga, Bogor 16680, West \\ Java, Indonesia. Tel.: +62 852-1931-0206, `email: junaedifaperta@gmail.com, ddarmadimsi@ gmail.com \\ ${ }^{4}$ Tohoku University. Aramaki Aza-Aoba, Aoba-ku, Sendai, Japan \\ ${ }^{5}$ Physiology Laboratory, Research Center for Biology, Indonesian Institute of Sciences. Jl. Raya Bogor Km. 46, Cibinong, Bogor 16911, West Java, \\ Indonesia
}

Manuscript received: 31 July 2019. Revision accepted: 3 September 2019.

\begin{abstract}
Darmadi D, Junaedi A, Sopandie D, Supijatno, Lubis I, Homma K, Hidayati N. 2019. Evaluation of water-saving rice status based on morphophysiological characteristics and water use efficiency. Biodiversitas 20: 2815-2823. One strategy to anticipate water shortages in rice production is to use varieties that are efficient in using water and produce high yields. The aim of this study was to measure water consumption, water use efficiency and production performance of several types of rice. The research was conducted during the rainy season from January to April 2018 and the dry season from August to November 2018 in a greenhouse. This study used a completely randomized design. The genetic materials used were 8 varieties consisting of lowland rice (sawah), upland rice (gogo), and landrace. The variables analyzed included morphological and physiological characteristics. The results showed that differences in rice types indicated diverse responses to morphological and physiological characteristics of water consumption and water use efficiency (WUE). Mentik Wangi variety had the highest water consumption of 24.1 liters. The IPB $9 \mathrm{G}$ and Jatiluhur varieties achieved the highest water use efficiency of 2.4 and 2.3, respectively. Based on the heatmap analysis, both varieties had similarities in the morphological characteristics of long roots, high root weights, long and broad leaves, and high total grain counts per panicle. The similarity of physiological characteristics was high rates of photosynthesis and low transpiration. Varieties that achieve the highest water use efficiency have the potential to be developed into varieties that are tolerant to limited water conditions.
\end{abstract}

Keywords: Leaf water potential, photosynthesis, hybrid varieties, and local varieties.

\section{INTRODUCTION}

Rice (Oryza sativa L.) is one of the three most important cereal plants and is a major food requirement that must be met throughout the world. The fulfillment of rice needs is related to current and future global food security (Chauhan et al. 2017). Rice production must always be increased to meet the food needs of the world's population which continues to increase in number. In 2017 , the increase in rice production reached 2.9 million tons of 759.6 million tons harvested dry grain or equivalent to 503.9 million tons of milled dry grain (FAO 2018). The occurrence of global warming in recent years has threatened the agricultural sector, especially related to the decline in rice yields in several tropical and subtropical regions (IPCC 2014). Rice cultivation activities must be able to adapt to these challenges. Efforts can be made by developing special cultivation technology on dry land with limiting factors of water availability.

Water has an important role in plant growth (Wang et al. 2012). Deficiencies can interfere all plant metabolic processes which have an impact on plant growth, plant development, and decrease in crop yields (Tripathy et al.
2000; Manikavelu et al. 2006; Venuprasad et al. 2011). The watering to rice plants must refer to the requirements of these plants. The water requirements of rice plants are based on the level of water consumption during their life cycle. The value of water consumption can then be used to calculate the value of water use efficiency (WUE) of plants. WUE value is calculated from the weight of grain produced in each unit volume of water consumed by rice plants (Tuong and Bouman 2003). Water consumption of rice plants in general in one planting season is $939.9 \mathrm{~mm}$ water or equivalent to rainfall of $7.77 \mathrm{~mm} \mathrm{day}^{-1}$ in the dry season.

An understanding of the level of consumption and the efficiency of water use in some types of rice can help the development of varieties and recommendations for suitable planting area in the future. Previous research by Supijatno et al. (2012) reported that rice which is efficient in using water has the same particular characteristics, i.e., thick leaves and small leaf area index. Water use efficiency is positively related to evapotranspiration and leaf greenness values and negatively associated with flowering time (Munawaroh et al. 2016). The important criterion for water use efficiency is the grain weight produced for each unit 
volume of consumed water (Supijatno et al. 2012). Plant performance is influenced by genotype and environmental factors, and genotype interactions with the environment. Genotypes or varieties will show different responses to different environments. Genotype interactions with the environment cause changes in the production value of varieties when planted in different ecologies. Research conducted by Supijatno et al. (2012) and Munawaroh et al. (2016) identified several differences in morphological, physiological, and production characteristics on water consumption and water use efficiency in one growing season. However, further studies regarding the differences in morphological, physiological, and production characteristics in the two seasons have not been carried out. Furthermore, the relationship between characteristics and the determination of the main characteristics with deeper analysis has not been conducted much, so there is some information that is not complete between these linkages. One further analysis that can be used is cluster analysis with visualization in the form of heatmap.

Heatmap Cluster Analysis (HCA) is used to simplify the interpretation of the data carried out by grouping the observed characters based on similarities or dissimilarities possessed (Schounlau 2004). Heatmap cluster analysis is an analysis that combines correlation and cluster analysis to facilitate understanding in an easy-to-understand form of visualization (Bowers 2010). The use of this analysis has been carried out by Janson et al. (2009) in metabolomics analysis to determine the biomarkers of Chorn disease, Zimisuhara et al. (2015) in Ficus deltoidea, Yuan et al. (2016) in potatoes on the morphological characteristics, Hanifah (2017) in eggplant on the metabolomic and morphological analysis, and Anshori et al. (2018) in rice on the heritability, characterization of dihaploid rice lines from anther culture results.. This study purpose to determine the characteristics of rice that are most efficient using water and have high production in two seasons (rainy and dry seasons).

\section{MATERIALS AND METHODS}

\section{Study area}

This research was carried out in the greenhouse of the Soil Research Institute, Indonesian Agency for Agricultural Research and Development, Laladon, Bogor, Indonesia. The study was conducted from January to November 2018. Analysis of chlorophyll and carotene was performed at post-harvest laboratories, Department of Agronomy and Horticulture, Faculty of Agriculture, IPB University. Analysis of stomata and leaf thickness was carried out at the Microtechnique Laboratory of the Department of Agronomy and Horticulture, Faculty of Agriculture, IPB University, Bogor, Indonesia. Analysis of leaf water potential was performed at the Physiology Laboratory, Indonesian Institute of Sciences, Bogor, Indonesia.

The materials used in this study were 8 rice varieties, i.e. Ciherang (inbred lowland rice), Mekongga (inbred lowland rice), Inpari 17 (inbred lowland rice), IPB $3 \mathrm{~S}$ (inbred lowland PTB rice), IPB 9 G (inbred upland rice),
Jatiluhur (inbred upland rice), Mentik Wangi (local lowland rice), Hipa 19 (hybrid lowland rice). This research used a 95-liter planting container. Control of pests and diseases was using bactericides, fungicides, and insecticides. Fertilizers used in this study included urea fertilizer, SP-36, and $\mathrm{KCl}$. Water used in the seedling, planting, maintenance and harvesting stages was water with a neutral $\mathrm{pH}$. The soil used for planting in 95-liter containers was from the Laladon rice field in Bogor, West Java Rice seeds before being planted were heated in oven at $40^{\circ} \mathrm{C}$ for 24 hours. The addition of water in containers was using a 1-liter measuring cup by daily watering. Thermometer was used to measure the temperature and humidity conditions in the greenhouse. The ruler was used to measure plant height, leaf length and width. Leaf area measurement was performed using the LI-3100C Area meter. The greenness of the leaves was measured using 502plus SPD (Soil Plant Analysis Development) instrument. LI-6400XT instrument was used to measure the photosynthesis rate, leaf temperature, and stomata conductance. Dewpoint potential meter was used to determine the leaf water potential.

This experiment of completely randomized design and 3 (three) replications. The treatment was 8 rice varieties. There were 24 experimental units and each experimental unit consisted of one container containing six clumps of plants which had a spacing of $20 \mathrm{~cm} \mathrm{x} 20 \mathrm{~cm}$. The measurement method of water consumption was based on Supijatno et al. 2012 with criteria of the size of 95-liter planting containers, while the observation of water consumption was performed daily, and maintained standing water in a $3 \mathrm{~cm}$ container. Soil moisture content was measured by the gravimetric method. The seeds of each variety were selected which had a uniform size. The seeds were soaked for 24 hours and sown in the nursery trays for 12 days. The nursery used was a dry nursery in a greenhouse.

The soil characteristics (Soil Research Center 1983) showed that media pH 5.7 (quite acidic); organic matter content: low $\mathrm{C}$ content of $1.73 \%$ (Walkey and Black method), low N content of $0.12 \%$ (Kjeldahl method), high C/N category of 14.42, P2O content 190 ppm (high); K2O 156 ppm (high); KTK (Cation Exchange Capacity) 30.94 me/100 g (high), alkali saturation $47 \%$ (moderate); sand, dust and clay textures of $3 \%, 66 \%$ and $31 \%$, respectively. Temperature measurements were made on every day. The average daily temperature is $27.6^{\circ} \mathrm{C}$. The maximum and minimum temperatures from the beginning of planting to harvesting were $39.0^{\circ} \mathrm{C}$ and $22.4^{\circ} \mathrm{C}$.

Plant maintenance was carried out by administering fertilizer with a dose equivalent to $250 \mathrm{~kg}$ Urea, $200 \mathrm{~kg} \mathrm{SP}$ 18 and $100 \mathrm{~kg} \mathrm{KCl} \mathrm{ha}^{-1}$. Urea fertilizer was given three times, while SP-18 and $\mathrm{KCl}$ fertilizers were given at the same time 2 weeks after planting (MST). Pest and disease controls were carried out according to the level of attack in the field. The water surface height was maintained at $3 \mathrm{~cm}$ from the ground surface during the growth period until 2 weeks before harvesting. The watering was stopped 14 days before the harvest. Harvesting was performed by 
looking directly at the panicles and grains of rice if they were yellow from 90 to $95 \%$.

The variables observed in this study included: (i) morphophysiological characteristics (plant height, number of productive tillers, leaf length, leaf width, leaf number, root length, harvesting age, number of filled grains per panicle, total grain count per panicle, root dry weight, shoot dry weight, pithy rice grain weight per clump, and productivity, total chlorophyll, carotene, leaf greenness, stomata number, water potential, photosynthetic rate, and transpiration), (ii) water consumption, (iii) water use efficiency. Calculation of water use efficiency (WUE) was using the ratio of dry grain weight compared to water consumption. Analysis of total chlorophyll was according to the methods of Sims and Gamons (2002). Photosynthesis analysis was measured using a Licor 6400 instrument. Stomatal conductance was measured using a Licor 6400 instrument. Leaf temperature was measured using a Licor 6400 instrument. Analysis of leaf water potential was using Dewpoint water potential instrument.

\section{Data analysis}

Data analysis included F-test, and clustering. The F-test was conducted to determine the significance of the treatment differences at $\alpha$ level of $5 \%$. If the results are significant, then further test of BNJ (Honestly Significance Difference is carried out at the $\alpha$ level of $5 \%$ to determine the differences between the observed varieties. Analysis of heatmap and clustering was carried out to determine the performance of each variety for each characteristic and classification of observed varieties. Data analysis was performed using STAR IRRI and R 3.5 with the package used consisted of the cluster, dextend, heatmap, heatmaply, and shiny

\section{RESULTS AND DISCUSSION}

\section{Performance of morphological characteristics}

Analysis of variance showed that varieties had a significant effect on all observed morphological characteristics (Table 1; Table 2). This shows that the influence of varieties can give different responses to observed characteristics genetically. The planting season had a significant effect on all characteristics observed except for leaf length, the water use efficiency, number of filled grain, total grain number, and shoot dry weight (Table 1; Table 2). The effect of significant $G \times E$ interactions on pithy rice grain weight shows that the genotype responds differently when planted in different seasons. The effect of $\mathrm{G} \times \mathrm{E}$ interactions that were not significantly different on water consumption showed that the genotype gave the same response in both seasons. The water use efficiency was strongly influenced by the weight of pithy rice grain produced and the volume unit of water consumed by the rice plants. Changes in pithy grain weight, followed by constant water consumption in different environmental conditions will result in changes in the value of water use efficiency.

\section{Performance of physiological characteristics}

Analysis of variance showed that rice varieties had a significant effect on all physiological characteristics observed except for the photosynthetic rate and transpiration (Table 3). This shows that the photosynthetic rate and transpiration did not differ between varieties. The seasons had a significant effect on all characteristics tested except for leaf greenness and stomata number (Table 3 ).

Table 1. Analysis of variance and average morphological characteristics of 8 rice varieties

\begin{tabular}{|c|c|c|c|c|c|c|c|c|}
\hline Variety & PH & NPT & $\mathbf{L L}$ & $\mathbf{L W}$ & $\mathbf{L N}$ & RL & WC & WUE \\
\hline Ciherang & 117.9 & 15.7 & 80.7 & 1.4 & 96.3 & 16.3 & 21.8 & 1.7 \\
\hline Mekongga & 118.3 & 16.8 & 83.1 & 1.5 & 106.2 & 14.9 & 21.1 & 1.5 \\
\hline Inpari 17 & 120.6 & 16.6 & 82.9 & 1.4 & 100.4 & 14.4 & 21.7 & 1.7 \\
\hline IPB $3 \mathrm{~S}$ & 139.4 & 8.2 & 94.3 & 1.9 & 51.8 & 25.1 & 20.7 & 1.5 \\
\hline Hipa 19 & 125.7 & 16.6 & 86.6 & 1.5 & 105.0 & 20.8 & 21.8 & 1.8 \\
\hline IPB $9 \mathrm{G}$ & 139.5 & 9.5 & 97.0 & 1.9 & 62.2 & 25.7 & 21.3 & 2.4 \\
\hline Jatiluhur & 140.4 & 11.2 & 95.6 & 1.9 & 69.7 & 27.4 & 22.1 & 2.3 \\
\hline Mentik Wangi & 123.1 & 17.5 & 82.5 & 1.6 & 96.0 & 24.4 & 24.1 & 1.8 \\
\hline Average & 128.1 & 14.0 & 87.8 & 1.6 & 85.9 & 21.1 & 21.8 & 1.8 \\
\hline $\mathrm{KK}(\%)$ & 2.29 & 8.87 & 3.00 & 4.12 & 10.34 & 11.95 & 3.23 & 11.25 \\
\hline BNJ 5\% & 5.5 & 3.3 & 5.0 & 0.1 & 16.8 & 4.8 & 1.3 & 0.5 \\
\hline \multicolumn{9}{|l|}{ F value of } \\
\hline Varieties (G) & $69.5 * *$ & $54.0 * *$ & $38.8 * *$ & $66.6^{* *}$ & $34.6^{* *}$ & $26.1 * *$ & $12.2 * *$ & $15.8 * *$ \\
\hline Season (E) & $9.7 *$ & $103.9 * *$ & $6.4^{\mathrm{ns}}$ & $25.7 *$ & $41.2 * *$ & $10.2 *$ & $54.1 * *$ & $0.1^{\mathrm{ns}}$ \\
\hline Interaction $\mathrm{G} \times \mathrm{E}$ & $0.8^{\mathrm{ns}}$ & $6.4^{* *}$ & $1.2^{\mathrm{ns}}$ & $2.2^{\mathrm{ns}}$ & $1.2^{\mathrm{ns}}$ & $0.46^{\mathrm{ns}}$ & $2.1^{\mathrm{ns}}$ & $3.8^{* *}$ \\
\hline
\end{tabular}

Note: PP: plant height (cm), NPT: number of productive tillers, LL: leaf length (cm), LW: leaf width (cm), LN: number of leaves, RL: root length $(\mathrm{cm})$, WC: water consumption (liter), WUE: water use efficiency, **: significantly different at level $1 \%$, *: significantly different at level $5 \%$, ns: not significantly different 
Table 2. Analysis of variance and average morphological characteristics of 8 rice varieties

\begin{tabular}{|c|c|c|c|c|c|c|c|}
\hline Variety & HA & NFG & NTG & RDW & SDW & WFG & PROD \\
\hline Ciherang & 103.5 & 116.4 & 135.9 & 19.0 & 47.0 & 36.3 & 6.0 \\
\hline Mekongga & 103.0 & 101.5 & 121.5 & 16.0 & 39.6 & 31.1 & 5.6 \\
\hline Inpari 17 & 103.5 & 114.7 & 139.2 & 12.5 & 40.3 & 37.5 & 5.6 \\
\hline IPB $3 \mathrm{~S}$ & 103.0 & 150.0 & 184.5 & 17.2 & 52.8 & 31.3 & 4.8 \\
\hline Hipa 19 & 103.0 & 122.9 & 155.2 & 18.5 & 40.8 & 39.7 & 7.0 \\
\hline IPB $9 \mathrm{G}$ & 107.2 & 218.7 & 249.7 & 21.0 & 52.3 & 50.6 & 6.7 \\
\hline Jatiluhur & 103.0 & 244.9 & 269.2 & 22.1 & 57.4 & 50.9 & 7.1 \\
\hline Mentik Wangi & 103.0 & 175.2 & 201.6 & 20.7 & 60.4 & 44.5 & 7.5 \\
\hline Average & 103.6 & 155.5 & 182.1 & 18.4 & 48.8 & 40.2 & 6.3 \\
\hline $\mathrm{KK}(\%)$ & 0.14 & 8.55 & 7.08 & 13.33 & 10.97 & 11.28 & 10.84 \\
\hline BNJ 5\% & 0.4 & 35.5 & 34.4 & 4.6 & 14.3 & 12.1 & 1.8 \\
\hline \multicolumn{8}{|l|}{$F$ value of } \\
\hline Varieties (G) & $597.6 * *$ & $95.0 * *$ & $107.9 * *$ & $9.8 * *$ & $13.8^{* *}$ & $17.7 * *$ & $11.1^{* *}$ \\
\hline Season (E) & $1681.0 * *$ & $2.5^{\mathrm{ns}}$ & $0.1^{\mathrm{ns}}$ & $21.9 * *$ & $7.7^{\mathrm{tn}}$ & $30.5 * *$ & $1581.3 * *$ \\
\hline Interaction $\mathrm{G} \times \mathrm{E}$ & $14.7 * *$ & $8.0 * *$ & $12.6 * *$ & $2.3^{\mathrm{tn}}$ & $9.1 * *$ & $3.3 *$ & $20.8 * *$ \\
\hline
\end{tabular}

Note: HA: harvesting age (days), NFG: number of filled grains per panicle, NTG: total grain per panicle, RDW: root dry weight (g), SDW: shoot dry weight (g), WFG: pithy grain weight (g), PROD: productivity (ton ha ${ }^{-1}$ ), **: significantly different at level $1 \%$, *: significantly different at level $5 \%$, ns: not significantly different

Table 3. Analysis of variance and average physiological characteristics of 8 rice varieties

\begin{tabular}{|c|c|c|c|c|c|c|c|}
\hline Variety & $\begin{array}{c}\text { Total } \\
\text { chlorophyll } \\
(\mathrm{mg} / \mathrm{g})\end{array}$ & $\begin{array}{c}\text { Carotene } \\
(\mathrm{mg} / \mathrm{g})\end{array}$ & $\begin{array}{c}\text { Leaf } \\
\text { greenery }\end{array}$ & $\begin{array}{c}\text { Number of } \\
\text { stomata } \\
\text { (units) }\end{array}$ & $\begin{array}{c}\text { Leaf water } \\
\text { potential } \\
(\mathrm{MPa})\end{array}$ & $\begin{array}{c}\text { Photosynthetic } \\
\text { rate } \\
\left(\mu \mathrm{mol} \mathrm{CO}_{2} \mathrm{~m}^{-2} \mathrm{~s}^{-1}\right)\end{array}$ & Transpiration \\
\hline Ciherang & 3.2 & 0.7 & 39.1 & 130.7 & -2.3 & 30.4 & 11.0 \\
\hline Mekongga & 2.8 & 0.7 & 40.7 & 124.0 & -2.3 & 31.0 & 10.4 \\
\hline Inpari 17 & 2.8 & 0.8 & 41.6 & 119.8 & -2.3 & 30.8 & 10.9 \\
\hline IPB $3 \mathrm{~S}$ & 2.0 & 0.6 & 41.4 & 122.5 & -2.1 & 30.5 & 11.5 \\
\hline Hipa 19 & 2.4 & 0.7 & 40.8 & 136.8 & -2.4 & 30.8 & 10.9 \\
\hline IPB $9 \mathrm{G}$ & 2.2 & 0.6 & 42.7 & 111.0 & -2.3 & 31.0 & 10.7 \\
\hline Jatiluhur & 1.9 & 0.6 & 40.6 & 100.3 & -2.1 & 31.3 & 10.6 \\
\hline Mentik Wangi & 1.7 & 0.5 & 33.6 & 130.7 & -2.5 & 30.6 & 11.3 \\
\hline Average & 2.4 & 0.7 & 40.1 & 122.0 & -2.3 & 30.8 & 10.9 \\
\hline $\mathrm{KK}(\%)$ & 20.58 & 14.47 & 3.59 & 6.47 & 7.24 & 7.70 & 6.62 \\
\hline BNJ 5\% & 0.9 & 0.2 & 2.7 & 21.1 & 0.4 & - & - \\
\hline \multicolumn{8}{|l|}{ F value of } \\
\hline Variety (G) & $6.5 * *$ & $3.8 * *$ & $22.8 * *$ & $13.4 * *$ & $4.1 * *$ & $0.1^{\mathrm{ns}}$ & $1.4^{\mathrm{ns}}$ \\
\hline Season $(E)$ & $47.4 * *$ & $100.2 * *$ & $3.8^{\mathrm{ns}}$ & $0.1^{\mathrm{ns}}$ & $10.7 *$ & $87.7 * *$ & $24.0 * *$ \\
\hline Interaction $\mathrm{G} \times \mathrm{E}$ & $2.2^{\mathrm{ns}}$ & $1.2^{\mathrm{ns}}$ & $1.5^{\mathrm{ns}}$ & $2.4^{*}$ & $9.5 * *$ & $0.5^{\mathrm{ns}}$ & $1.3^{\mathrm{ns}}$ \\
\hline
\end{tabular}

Note: **: significantly different at level 1\%, *: significantly different at level 5\%

Season or environmental differences di not show any influence on these two characteristics. Therefore genetic factors can be assumed to play a significant role. The interaction between variety $(\mathrm{G})$ and season $(\mathrm{E})$ showed a significant effect on the number of stomata and the leaf water potential. This shows that a change in the environment will be followed by a different response to the two characteristics. The effect of varieties gave a variety in total chlorophyll and carotene content between varieties. The effect of season also gave a variety in total chlorophyll and carotene content between seasons. The interaction of $\mathrm{G}$ $\mathrm{x} E$ was not significantly different, indicating that the total chlorophyll and carotene content of the variety (V) did not show a response due to seasonal changes (E). This is presumably because the plants grew at optimum conditions even though the season was different. The Ciherang variety had the highest total chlorophyll of $3.2 \mathrm{mg} / \mathrm{g}$ fresh weight, while the lowest total chlorophyll was in the Mentik Wangi variety. The highest carotene content was in the Inpari 17 variety, while the lowest carotene content was in the Mentik Wangi variety. The highest leaf greenness was obtained the IPB $9 \mathrm{G}$ variety. The highest number of stomata was obtained in the Hipa 19 variety of 136.2 stomata.

\section{Correlation of morphophysiological characteristics on water consumption and WUE}

Correlation analysis is used to observe relationships between characteristics. Correlation analysis was carried out in 2 seasons, i.e., dry season and rainy season. The 
results of the correlation analysis showed that water consumption had a positive and significant correlation with shoot dry weight $(\mathrm{r}=0.720, \mathrm{P}<0.05)$ in the rainy season, whereas in the dry season water consumption did not show a correlation. Water consumption had a significant and negative correlation with carotene content $(r=-0.828$, $\mathrm{P}<0.05)$ in the dry season. Water consumption had a negative and significant correlation with leaf greenness $(r=$ $-0,809, \mathrm{P}<0.05)$ in the dry season, as well as leaf greenness $(\mathrm{r}=-0,856, \mathrm{P}<0.05)$ in the dry season. Water consumption had a negative and significant correlation with leaf water potential $(\mathrm{r}=-0.839, \mathrm{P}<0.01)$ in the rainy season. In contrast, water consumption had a positive and significant correlation with transpiration $(\mathrm{r}=0.734, \mathrm{P}<0.05)$ in the rainy season.

Water use efficiency had a positive and significant correlation with leaf length $(\mathrm{r}=0.823, \mathrm{P}<0.05)$ and root length $(\mathrm{r}=0.816, \mathrm{P}<0.05)$ in the rainy season. Water use efficiency had a positive and significant correlation with the number of filled grain per panicle $(r=0.902, \mathrm{P}<0.01)$ in the rainy season and the number of filled grain per panicle $(r=0.756, \mathrm{P}<0.01)$ in the dry season. Water use efficiency had a positive and significant correlation with the total grain count per panicle $(r=0.921, \mathrm{P}<0.01)$ in the rainy season and total grain count per panicle $(\mathrm{r}=0.713, \mathrm{P}$ $<0.01$ ) in the dry season. Water use efficiency had a positive and significant correlation with pithy rice grain weight $(\mathrm{r}=0.948, \mathrm{P}<0.01)$ in the rainy season and pithy rice grain weight $(\mathrm{r}=0.990, \mathrm{P}<0.01)$ in the dry season. Water use efficiency had a positive and significant correlation with productivity $(\mathrm{r}=0.946, \mathrm{P}<0.01)$ in the rainy season.

Characteristic that still shows a positive correlation with genetics despite different environmental conditions then indicates genetic factors play a major role. The characteristic of the number of filled grain per panicle and pithy grain weight had a positive and significant correlation to the water use efficiency both in rainy and dry seasons. This shows that these characteristics can be used as an indicator that characteristics which have high water use efficiency will also produce a high number of pithy grain per panicle and high pithy grain weight.

\section{Evaluation of rice varieties classification based on morphological characteristics}

The heatmap clustering analysis aimed to investigate the relationship between WUE characteristic, water consumption, agronomic characteristics, and morphological characteristics in the two seasons (Figure 1). Figure 1 shows two types of classification, i.e., classification based on varieties in the line and classification based on agronomic characteristics, morphology, water consumption, and WUE in the column.

The general pattern in Figure 1 shows three classified groups, i.e., i) the first group was based on the similarity in characteristics of high number of filled grain per panicle, high total grain number, long root, and high shoot dry weight. In this group there are three varieties: IPB 9 G, IPB $3 \mathrm{~S}$, and Jatiluhur; ii) the second group was based on similarity in characteristics of the low number of filled grain per panicle, low total grain number, short roots, and small shoot dry weight. In this group there are four varieties: Ciherang, Mekongga, Inpari 17, and Hipa 19, iii) the third group had the characteristics of a high number of productive tillers, a large number of leaves, and high productivity. The variety in this group is only the Mentik Wangi variety.

Table 4. Correlation analysis of morphophysiological characteristics on water consumption and water use efficiency in the dry and rainy seasons

\begin{tabular}{|c|c|c|c|c|}
\hline \multirow{2}{*}{ Characteristic } & \multicolumn{2}{|c|}{ Water consumption } & \multicolumn{2}{|c|}{ Water use efficiency } \\
\hline & Rainy season & Dry season & Rainy season & Dry season \\
\hline Plant height & -0.336 & -0.066 & 0.832 & 0.298 \\
\hline Number of productive tillers & 0.387 & 0.457 & -0.598 & -0.095 \\
\hline Leaf length & -0.498 & -0.089 & $0.823 *$ & 0.355 \\
\hline Leaf width & -0.377 & 0.035 & 0.681 & 0.262 \\
\hline Number of leaves & 0.352 & 0.305 & -0.673 & -0.033 \\
\hline Root length & 0.150 & 0.362 & $0.816^{*}$ & 0.351 \\
\hline Harvest age & -0.261 & -0.175 & 0.568 & 0.616 \\
\hline Number of filled grain per panicle & 0.157 & 0.335 & $0.902 * *$ & $0.756^{*}$ \\
\hline total grain count per panicle & 0.123 & 0.319 & $0.921 * *$ & $0.713^{*}$ \\
\hline Root dry weight & 0.262 & 0.322 & 0.649 & 0.519 \\
\hline Shoot dry weight & $0.720 *$ & 0.465 & -0.207 & 0.506 \\
\hline Pithy grain weight & 0.238 & 0.490 & $0.948 * *$ & $0.990 * *$ \\
\hline Productivity & 0.244 & 0.451 & $0.946 * *$ & -0.061 \\
\hline Total Chlorophyll & -0.150 & -0.555 & -0.417 & -0.432 \\
\hline Carotene & -0.211 & $-0.828 *$ & -0.456 & -0.481 \\
\hline Leaf greenness & $-0.809 *$ & $-0.856^{* *}$ & -0.809 & -0.029 \\
\hline Number of stomata & 0.454 & -0.174 & -0.356 & -0.619 \\
\hline Leaf water potential & $-0.839 * *$ & -0.373 & -0.054 & -0.503 \\
\hline Photosynthetic rate & -0.343 & 0.109 & 0.609 & 0.498 \\
\hline Transpiration & $0.734 *$ & 0.076 & -0.526 & -0.305 \\
\hline
\end{tabular}

Note: **significantly different at $\mathrm{P}<0.01$, * significantly different at $\mathrm{P}<0.05$ 


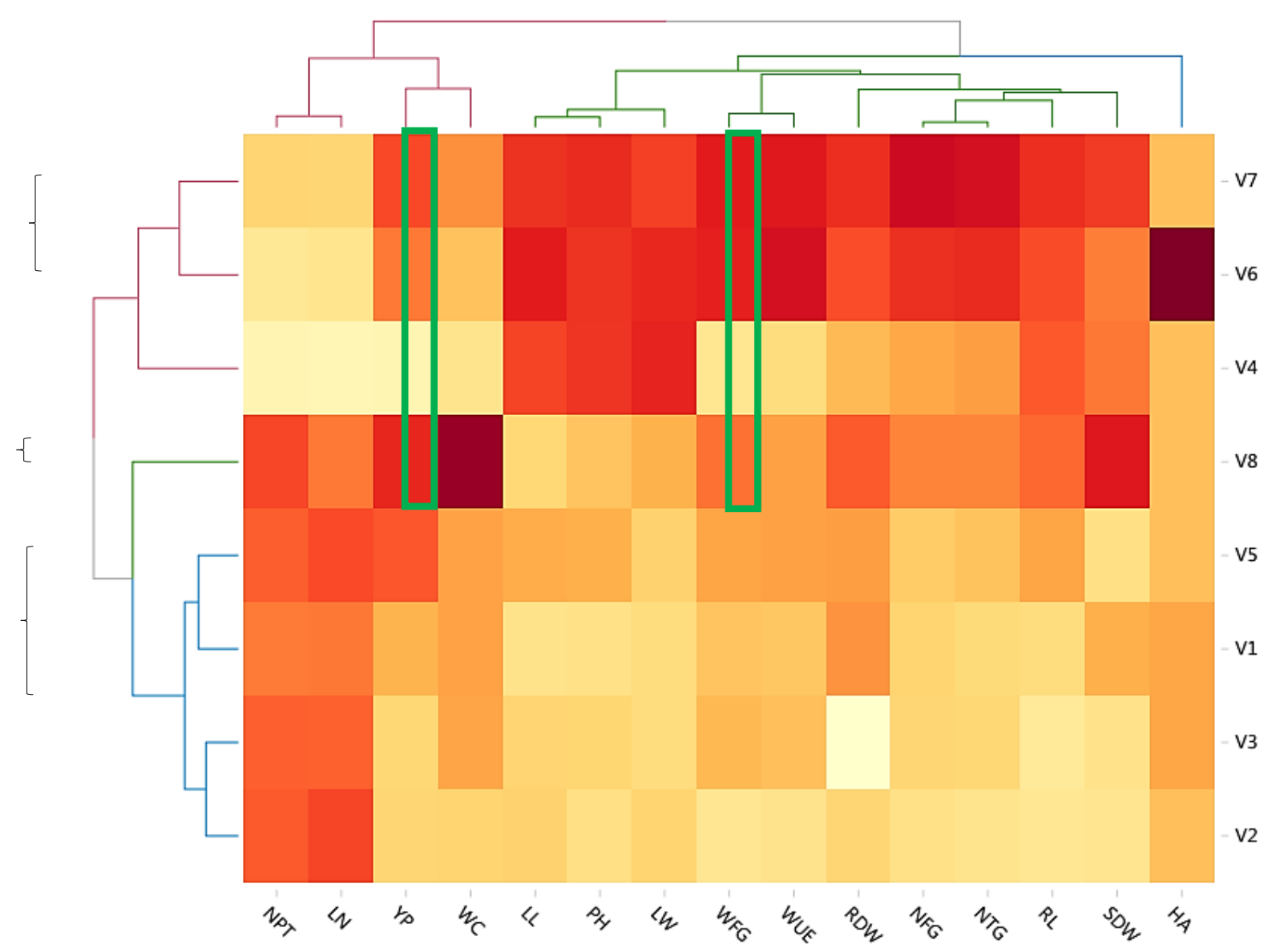

Figure 1. Heatmap analysis of morphological characteristics, water consumption, and water use efficiency. PH: plant height, NPT: number of productive tillers, LL: leaf length, LW: leaf width, LN: number of leaves, RL: root length, WC: water consumption, WUE: water use efficiency, HA: harvesting age, NFG: number filled grain per panicle, NTG: total grain count per panicle, RDW: root dry weight, SDW: shoot dry weight, WFG: pithy grain weight, YP: productivity; V1: Ciherang, V2: Mekongga, V3: Inpari 17, V4: IPB 3 S, V5: Hipa 19, V6: IPB 9 G, V7: Jatiluhur, V8: Mentik Wangi; A, B, C = General pattern; a, b = special pattern.

Special patterns in the character of water consumption classified varieties into 3 groups; i) variety that consume a lot of water includes 1 variety Mentik Wangi, ii) variety that consume medium (moderate) water includes 4 varieties, i.e., Ciherang, Hipa 19, Inpari 17 and Jatiluhur, and iii) variety that consume little water includes 2 varieties Mekongga and IPB $3 \mathrm{~S}$.

Special patterns in the character of WUE classified varieties into 3 groups; i) the most efficient varieties are 2 varieties, i.e., Jatiluhur and IPB $9 \mathrm{G}$, ii) moderate variety includes 1 variety Hipa 19, and iii) the most inefficient varieties are 5 varieties, i.e., Inpari 17, Mekongga, Ciherang, IPB $3 \mathrm{~S}$ and Mentik Wangi. There are still many other special patterns depending on which characteristics want to be understood in the study (Figure 1).

\section{Discussion}

Performance of morphological characteristics

The performance of morphological characteristics is presented in Table 1 and Table 2. The IPB $3 \mathrm{~S}$, Jatiluhur, and IPB $9 \mathrm{G}$ varieties had the highest plant height and a small number of productive tillers. The three varieties had long and wide leaves but had fewer leaves compared to other varieties. Ciherang, Mekongga, and Inpari 17 varieties had medium plant height and a large number of productive tillers. IPB $3 \mathrm{~S}$, Jatiluhur, and IPB $9 \mathrm{G}$ varieties had long and wide leaves but had fewer leaves compared to other varieties. Jatiluhur variety had the longest root of $27.4 \mathrm{~cm}$. The lowest leaf water potential was obtained in the Mentik Wangi variety of -2.5 . Jatiluhur and IPB 9 G varieties are varieties that were efficient in water use (Table 1), had water potentials of -2.1 and -2.3 , respectively. Status of plants water is expressed as leaf water potential. The leaf water potential value that is lower than the potential of groundwater will make water absorbable by plants. Total leaf water potential during transpiration ranges from -0.5 to $-3.0 \mathrm{MPa}$ (Hariyati and Musdiyarso 2004). The lowest leaf water potential $(\psi \mathrm{d})$ during drought stress ranges from $0.046 \mathrm{MPa}$ to $0.056 \mathrm{MPa}$ (Reis et al. 2018; Santos et al. 2018). 


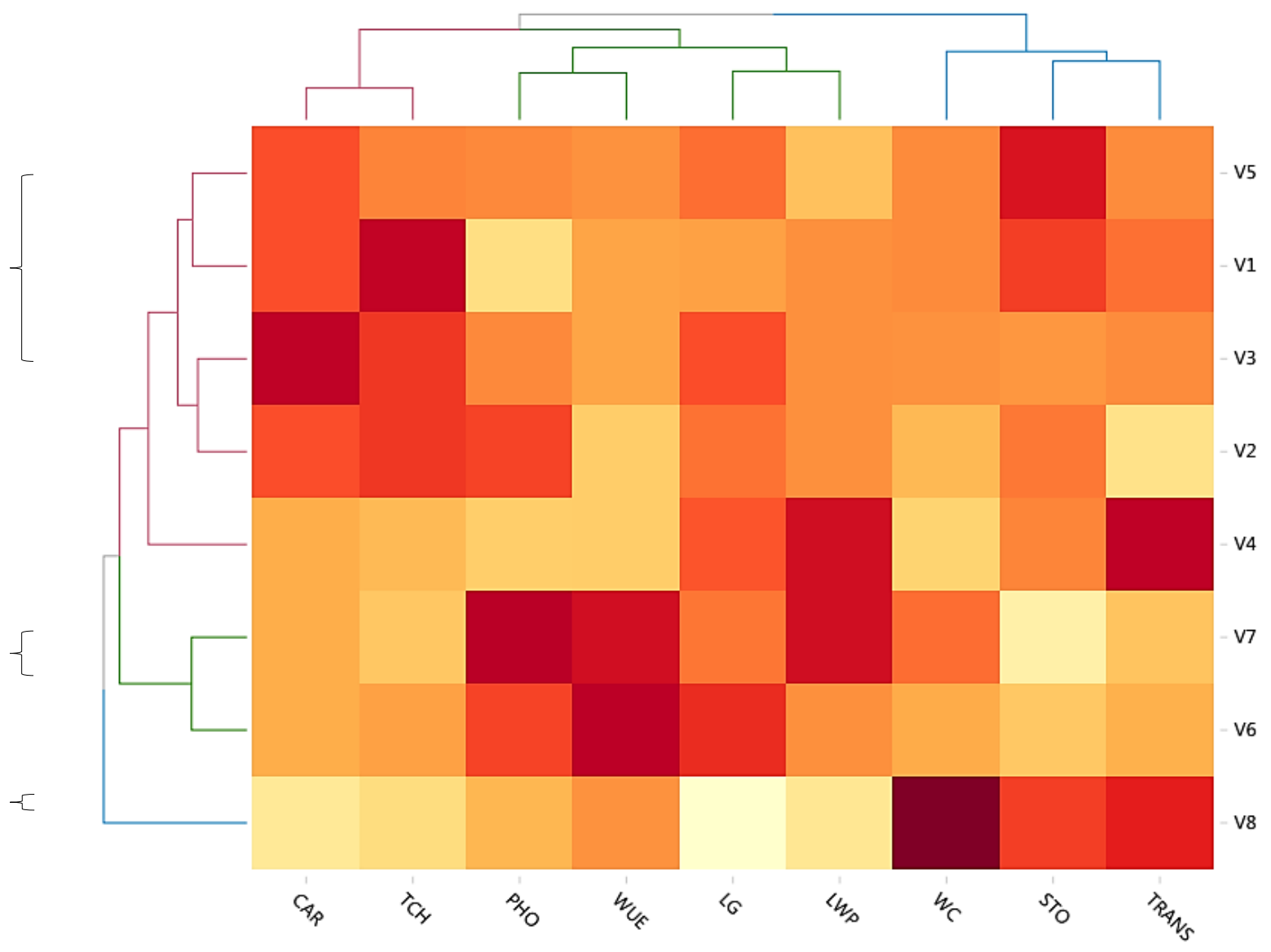

Figure 2. Heatmap analysis of physiological characteristics, water consumption, and water use efficiency. LWP: leaf water potential, CAR: carotene, WUE: water use efficiency, TCH: total chlorophyll, TRANS: transpiration, WC: water consumption, PHO: photosynthetic rate, LG: leaf greenness, STO: number of stomata, V1: Ciherang, V2: Mekongga, V3: Inpari 17, V4: IPB 3 S, V5: Hipa 19, V6: IPB 9 G, V7: Jatiluhur, V8: Mentik Wangi; A, B, C = General pattern

The highest rate of photosynthesis was obtained in the Jatiluhur variety, which was $31.3 \mu \mathrm{mol} \mathrm{CO}_{2} \mathrm{~m}^{-2} \mathrm{~s}^{-1}$, while the lowest rate of photosynthesis was in the Ciherang variety at $30.4 \mu \mathrm{mol} \mathrm{CO}_{2} \mathrm{~m}^{-2} \mathrm{~s}^{-1}$. The highest transpiration was obtained in the IPB $3 \mathrm{~S}$ variety of 11.5 , while the lowest transpiration was in the Mekongga variety of 10.4. The characteristic of water use efficiency had a positive correlation with the rate of photosynthesis, stomatal conductance, and relative leaf water content. In contrast, it showed a negative correlation with transpiration of basmati rice in drought conditions (Akram et al. 2013).

The Mentik Wangi and Jatiluhur varieties had the highest water consumption of 24.1 liters and 22.1 liters, while the IPB $3 \mathrm{~S}$ variety had the lowest water consumption of 20.7 liters. The morphological characteristics of plants that consumed much water are plants that have a high plant height, a large number of tillers, a large leaf area index, and a long root. The IPB $9 \mathrm{G}$ and Jatiluhur varieties had the highest water use efficiency of 2.4 and 2.3 respectively, while the Mekongga and IPB 3 $\mathrm{S}$ varieties had the lowest water use efficiency of 1.5 and 1.5 , respectively. Ritchie (1983) reported that water use efficiency correlates with leaf area and leaf area index.
Long and wide leaves will increase leaf area so that plants can be efficient in water use. WUE values also positively correlated with number of tillers, the width of flag leaf, and the number of leaves (Sulistyono et al. 2005).

The tested varieties had a fast harvesting age, ranging from 103.0 to 107.2 days (Table 2). The IPB $9 \mathrm{G}$ and Jatiluhur varieties had the largest number of filled grains per panicle of 218.7 grains, and 244.9 grains, respectively. The highest dry weight root was obtained in the Jatiluhur variety, while the highest shoot dry weight was obtained in the Mantik Wangi variety. The highest filled grain number was obtained in IPB $9 \mathrm{G}$ and Jatiluhur varieties. The characteristics of high filled grain number will affect the value of water use efficiency. The expected varieties are varieties that have high water use efficiency and low water consumption. The highest productivity was obtained in Mentik Wangi variety (7.5 tons $\mathrm{ha}^{-1}$ ) and Jatiluhur (7.1 tons $\left.\mathrm{ha}^{-1}\right)$. High productivity in Mentik Wangi variety is also indicated by its high consumption of water. At optimum conditions, this type of rice can be cultivated, but in lack of water conditions, this type of rice is not efficient in cultivation practices. 


\section{Evaluation of rice varieties classification based on} physiological characteristics

Characteristics that were not significantly different due to the influence of the seasons can be expected because of the optimum environmental conditions despite differences in the planting seasons. The optimum conditions are apparently because the water requirements for plants were sufficient, and the controlled conditions of the greenhouse environment. Environmental conditions that gave a significant influence on leaf length and yield components was when the environment is lacking in water. The water shortage effects are shrinking leaves, decreasing yield components, and decreasing shoot dry weight (Centritto et al. 2009; Farooq et al. 2010; Mostajeran and Rahimi-Eichi 2009), so that differences in environmental conditions will be easily observed.

The interaction between variety $(\mathrm{G})$ and season $(\mathrm{E})$ showed a significant effect on the number of productive tillers, water use efficiency, harvesting age, number of filled grains per panicle, total grain per panicle, shoot dry weight, pithy grain weight, and productivity. Significant effects of $G \times E$ interactions illustrate differences in genotype responses in different environmental conditions (Hidayatullah et al. 2018; Sharifi et al. 2017). The relationship of physiological characteristics on water consumption and WUE is shown in Figure 2. The general pattern formed in Figure 2 shows three classified groups, i.e., the first group was based on the similarity in characteristics of high total chlorophyll, high carotene, and high photosynthetic rate. In this group there are 5 varieties, i.e., Ciherang, Mekongga, Inpari 17, IPB 3 S, and Hipa 19; ii) the second group was based on the similarity in characteristics of high photosynthetic rate, high leaf greenness, high water potential. This group includes 2 varieties, i.e., IPB $9 \mathrm{G}$ and Jatiluhur; iii) third group has characteristics of high transpiration, high stomata, low water potential, and moderate photosynthetic rate, i.e., Mentik Wangi variety.

Mentik Wangi variety had the largest water consumption. Physiologically, the characteristics of Mentik Wangi varieties were low in carotene content, total chlorophyll, and leafy greenness. The variety that had the lowest water consumption is IPB 3 S. Physiologically, the characteristics of this variety were low water use efficiency, high transpiration, and high leaf greenness. The Mentik Wangi variety is in the same group with Ciherang variety based on the characteristics of low water use efficiency, relatively high transpiration, and relatively large number of stomata. The relationship of physiological characteristics on the water use efficiency is presented in Figure 2. Jatiluhur and IPB $9 \mathrm{G}$ varieties had the highest water use efficiency. The physiological characteristics of the two varieties were low in carotene content, total chlorophyll, transpiration, but high in photosynthetic rates.

\section{Correlation of morphophysiological characteristics on water consumption and WUE}

Varieties that had high water use efficiency will produce high content of grain. The same results were obtained by Munawaroh et al. (2016) that the characteristics of the number of filled grain per panicle, total grain count per panicle, root dry weight, shoot dry weight, and pithy grain weight had a positive correlation with the efficiency of water use. Environmental differences due to the effect of seasonal change can give influence on the relationship among characteristics. Characteristics that have a good correlation in the dry season and rainy season indicate that these characteristics have a strong relationship. In contrast, characteristics only show correlation in one environment has a weak relationship. This illustrates that the correlation between characteristics is influenced by environmental conditions. Akram et al. (2013) explained that the characteristic of water use efficiency has a positive correlation with photosynthetic rate, stomatal conductance, and relative leaf water content, and on the contrary, it has a negative correlation with transpiration in basmati rice drought conditions (Akram et al. 2013).

\section{Evaluation of rice varieties classification based on morphological characteristics}

The clustering analysis used red as an indicator of the strength of relationships between characteristics. Characteristic that had high values are indicated by colors that are increasingly concentrated according to the scale stated in the image, while weak characteristic has an increasingly bright color. Color intensity in clustering analysis shows the level of strength or degree of genotype in each characteristic. The more concentrated color of a genotype of a characteristic resulted in higher genotype values of the characteristic. This can provide an easy understanding of determining the characteristics of the genotype group by looking at color contrast between groups (Lee et al. 2016).

In conclusion, variations in various types of rice showed very diverse responses in the morphological and physiological characteristics of water consumption and WUE. Evaluation of water-saving rice status based on the heatmap analysis for morphological and physiological characteristics showed that the variety required high water consumption was Mentik Wangi variety including the local lowland rice type varieties. In contrast, the most efficient variety in using water was IPB $9 \mathrm{G}$ including the new type of rice (PTB) lowland rice. Based on the evaluation, watersaving rice had the characteristics of long roots, high root weights, long and wide leaves, and high total grain counts per panicle, high photosynthetic rate and low transpiration. The high WUE values have the opportunity to be developed in optimal soil conditions, because they have high yield and optimal use of water for better grain production.

\section{ACKNOWLEDGEMENTS}

The authors would like to thank the Ministry of Agriculture, the Indonesian Agency for Agricultural Research and Development for providing funds to conduct this research through the Study Research Assistance Program of the Indonesian Agency for Agricultural Research and Development. 


\section{REFERENCES}

Akram HM, Ali A, Sattar A, Rehman HSU, Bibi A. 2013. Impact of water deficit stress on various physiological and agronomic traits of three basmati rice (Oryza sativa L.) cultivars. J Anim Plant Sci 23 (5): 1415-1423.

Anshori MF, Purwoko BS, Dewi IS, Ardie SW, Suwarno WB, Safitri H. 2018. Heritabilitas, karakterisasi, dan analisis clustergram galur-galur padi dihaploid hasil kultur antera. J. Agron. Indonesia. 46 (2): 119 125.

Bowers AJ. 2010. Analyzing the longitudinal K-12 grading histories of entire cohorts of students: grades, data-driven decision making, dropping out and hierarchical cluster analysis. Practical Assessment. Res. Eval.15: 1-18.

Centritto M, Lauteri M, Monteverdi MC, Serraj R. 2009. Leaf gas exchange, carbon isotope discrimination, and grain yield in contrasting rice genotypes subjected to water deficits during the reproductive stage. J Exp Bot 60 (8): 2325-2339.

Chauhan BS, Jabran K, Mahajan G. 2017. Rice Production Worldwide. Springer International Publishing AG. Switzerland.

Farooq M, Kobayashi N, Ito O, Wahid A, Serraj R. 2010. Broader leaves result in better performance of indica rice under drought stress. J Plant Physiol1 67 (13): 1066-1075.

[FAO] Food and Agriculture Organization. 2016. Rice market monitor Volume XIX no 4. http: //www.fao.org/economic/RMM [14 January 2019].

Hanifah A. 2017. Analisis Metabolomik dan Morfologi Beberapa Aksesi Terung (Solanum melongena L.). Thesis. Sekolah Pasca Sarjana IPB. Institut Pertanian Bogor. 57 p.

Hariyati NF, Murdiyarso D. 2004. Hubungan air tanaman Acasia mangium Willd, di Hutan Tanaman, Perum Perhutani Bogor. Jurnal Agromet 19 (2) : 13-23.

Hidayatullah A, Purwoko BS, Dewi IS, Suwarno WB. 2018. Agronomic performance and yield of doubled haploid rice lines in advanced yield trial. SABRAO J. Breed. Genet. 50 (3): 242-53.

IPCC. 2014. Climate Change 2014: Synthesis Report. Contribution of Working Groups I, II and III to the Fifth Assessment Report of the Intergovernmental Panel on Climate Change [Core Writing Team, R.K. Pachauri and L.A. Meyer (eds.)]. IPCC, Geneva, Switzerland, $151 \mathrm{pp}$.

Jansson J, Willing B, Lucio M, Fekete A, Dicksved J, Tysk, Kopplin SP, Halfvarson J. 2009. Metabolomics reveals metabolic biomarkers of Crohn's disease. PLoS ONE. 7 (4): 1-10.

Lee JE, Recker AJ, Bowers M, Yuan. 2016. Hierarchical cluster analysis heatmaps and pattern analysis: an approach for visualizing learning management system interaction data. Proceeding of The 9th International Conference on Educational Data Mining. North Carolina. USA

Manikavelu A, Nadarajan N, Ganesh SK, Gnanamalar RP, Chandra BR. 2006. Drought tolerance in rice: Morphological and molecular genetic consideration. Plant Growth Regul 50 (2/3): 121-138.

Mostajeran A, Rahimi-Eichi V. 2009. Effects of drought stress on growth and yield of rice (Oryza sativa L.) cultivars and accumulation of proline and soluble sugars in sheath and blades of their different ages leaves. Am-Eur J Agric Environ Sci 5 (2): 264-272.

Munawaroh L, Sulistyono E, Lubis I. 2016. Karakter morfologi dan fisiologi yang berkaitan dengan efisiensi pemakaian air pada beberapa varietas padi gogo. J. Agron. Indonesia 44 (1) : 1 - 7.

Reis AFB, Almeida REM, Lago BC, Trivelin PC, Linquist B, Favarin JL. 2018. Aerobic rice system improves water productivity, nitrogen recovery and crop performance in Brazilian weathered lowland soil. Field Crop. Res.218: p. 59-68.

Ritchie JT. 1983. Efficient water use in crop production: Discussion on the generally relations between biomass production and evapotranspiration. In: Taylor HM, Jordan WR, Sinclair TS (eds). Limitation to Efficient Water Use in Crop Production. Amer. Soc. of Agron. Inc. Wisconsin. p. 29-44.

Santos CLd, Reis AfdB, Mazzafera P, Favarin JL. 2018. Determination of the water potential threshold at which rice growth is impacted. $\mathrm{J}$. Plants 7 (3): 48

Schonlau M. 2002. The cluster gram: A graph for visualizing hierarchical and nonhierarchical cluster analyses. Stata J. 2: 391-402.

Sharifi P, Aminpanah H, Erfani R, Mohaddesi A, Abbasian A. 2017. Evaluation of Genotype $\mathrm{x}$ Environment Interaction in Rice Based on AMMI Model in Iran. Rice Sci 24 (3): 173-80.

Sims DA dan Gamon JA. 2002. Relationships between leaf pigment content and spectral reflectance across a wide range of species, leaf structures and developmental stages. Remote Sensing of Environment 81: 337- 354

Supijatno, Chozin MA, Sopandie D, Trikoesoemaningtyas, Junaedi A, dan Lubis I. 2012. Evaluasi konsumsi air beberapa genotipe padi untuk potensi efisiensi penggunaan air. J Agron Indonesia. 40 (1): 15-20.

Sulistyono E, Suwarto, Ramdiani Y. 2005. Defisit Evapotranspirasi sebagai Indikator Kekurangan Air pada Padi Gogo (Oryza sativa L.). Bul. Agron 33 (1): 6 - 11

Tripathy JN, Zhang JX, Robin S, Nguyen TT, Nguyen HT. 2000. QTLs for cell-membrane stability mapped in rice (Oryza sativa L.) under drought stress. Theor Appl Genet 100 (8): 1197-1202.

Tuong TP, Bouman BAM. 2003. Rice production in water-scarce environments. In: Kijne JW, Barker R, Molden D. 2003. Water productivity in agriculture: Limits and opportunities for improvements. Comprehensive Assessment of Water Management in Agriculture Series 1, CABI International, UK, pp. 53-68.

Venuprasad R, Impa SM, Vowda GRP, Atlin GN, Serraj R. 2011. Rice near-isogenic-lines (NILs) contrasting for grain yield under lowland drought stress. Field Crops Res 123 (1): 38-46.

Wang JH, Geng LH, Zhang CM. 2012. Research on the weak signal detecting technique for crop water stress based on wavelet denoising. Adv Mat Res, 424/425: 966-970.

Yuan J, Murphy A, Koeyer DD, Lague M, Bizimungu B. 2016. Effectiveness of the field selection parameters on potato yield in Atlantic Canada. Can. J. Plant Sci. 96: 701-710.

Zimisuhara B, Valdiani A, Shaharuddin NA, Qamaruzzaman F, Maziah M. 2015. Structure and principal component analyses reveal an intervarietal fusion in Malaysia mistletoe fig (Ficus deltoidea Jack) population. Int. J. Mol. Sci 16: 14369-14394. 